\title{
Application of Experiential Learning to Improve Student Engagement and Experience in a Mechanical Engineering Course
}

Huaizhong Li*, Andreas Öchsner and Wayne Hall

Griffith School of Engineering, Gold Coast campus, Griffith University, QLD 4222, Australia

* Corresponding to: Dr Huaizhong Li, Griffith School of Engineering, Gold Coast campus, Griffith University, QLD 4222, Australia. E-mail: lihuaizhong@gmail.com;

h.li@griffith.edu.au. Telephone: +61 (7) 5552 8252; Facsimile: +61 (7) 55528062

Biographical notes:

Dr Huaizhong Li is a Senior Lecturer in Mechanical Engineering at Griffith University, Australia. He obtained a B.E. degree from Tsinghua University, M.E. from Xi'an Jiaotong University, and Ph.D. from the National University of Singapore. Before joining Griffith University in 2014, he worked as a Senior Research Engineer at Singapore Institute of Manufacturing Technology, Associate Principal Engineer at Vestas, and Lecturer at UNSW Australia. His research interests include advanced manufacturing technologies, machine dynamics, vibration control, and mechatronics. He has published over 70 refereed technical articles in international journals and conference proceedings.

Professor Andreas Öchsner is Full Professor in the School of Engineering at Griffith University and Head of the Mechanical Engineering Program and Discipline. His research interests are related to experimental and computational mechanics, cellular metals and thin structures and interphases. His editorial work comprises appointments as Editor-in-chief of the international journal Continuum Mechanics and Thermodynamics (Springer) and Editor-in-chief of the Springer book series on Advanced Structured Materials. His research activities were recognised in 2010 by the award of a higher doctorate degree (D.Sc.) by the University of Newcastle, Australia.

Dr Wayne Hall holds a BEng (Hons) degree in Mechanical Engineering from the University of Sunderland and a PhD from the University of Warwick (UK). Before taking up his current position as a Senior Lecturer at Griffith University (Australia), he worked at Deakin University 
(Australia) and the University of Plymouth (UK). His research interests lie in fibre reinforced polymer composites and engineering education, particularly Project Based Learning (PBL).

Word count: 5861 


\title{
Application of Experiential Learning to Improve Student Engagement and Experience in a Mechanical Engineering Course
}

\author{
Abstract: This paper introduced how a mechanical engineering course was \\ redesigned by applying experiential learning theory to improve student \\ engagement and learning experience. Design of machine elements has been \\ considered by students to be a difficult course. Traditional teaching methods tend \\ not to be effective in engaging students. Experiential learning is a philosophy of \\ learning by doing. In applying an experiential learning approach to the course, \\ the design project and workshop activities were restructured in such a way that \\ students were engaged in direct experience and focused reflection to construct \\ knowledge. By exploring a physical gearbox model, working on subtasks for the \\ design project, having group discussions, raising questions, getting feedback, and \\ moving forward for next subtasks, students experienced the learning cycles of \\ 'DO, OBSERVE, THINK, and PLAN' many times. Course survey results \\ showed that application of experiential learning helped to improve student \\ engagement and learning experience significantly.
}

Keywords: Engineering Education, Experiential Learning, Machine Design, Machine Elements, Project Based Learning

\section{Introduction}

Undergraduate mechanical engineering students in universities are required to study several core mechanical engineering design courses, such as Design of Machine Elements. To compete in the global market, it is required from the industry that mechanical engineers today must demonstrate skills like multidisciplinary knowledge, excellent communication capabilities, and inquisitiveness. Recent studies have revealed that the demands of technical and personal abilities required of engineering graduates by today’s industry are unlikely to be satisfied by a traditional engineering curriculum and teaching approach (Mills and Treagust 2003). For example, there is a huge gap in some demands such as the lack of strong communication and teamwork skills, a broader 
perspective of the issues that concern their profession, and good knowledge of fundamental engineering science (Sohel et al. 2011; Mills and Treagust 2003). The traditional approach of lecture-based theory teaching results in passive learning and seems to be ineffective and less suitable for training modern students to meet the current demands of industry. It is therefore important to improve students' learning experiences through introducing some emerging perspectives in learning and teaching. Active learning should be used which is considered to be effective in improving students' attention and is able to engage students in taking a deep approach to their learning (Biggs and Tang 2011).

Project-based learning (PBL) is a student-centred methodology eminently suited to engineering design education. Palmer and Hall (2011) provided a comprehensive review of the literature related to PBL. The methodology claims to offer a number of educational benefits (including development of effective design solutions under realistic conditions, experience and development of teamwork, self-motivation and student ownership of the learning) that will improve the educational outcomes and employability of engineering graduates. Design is considered one of the central functions of engineering practice and hence it is essential that students are exposed to 'real-world’ conditions (Hall, Palmer, and Bennett 2012). The use of project-based learning as a key component of engineering programs should be promulgated as widely as possible according to Mills and Treagust (2003). A recent study (Han, Capraro, and Capraro 2015) showed that PBLs benefited low performing students to a greater extent and decreased the achievement gaps. It is a central theme in Engineering Design courses at Griffith University (for example, 1006ENG Design and Professional Skills, and 2502ENG Mechanical Engineering Design), but is also finding favour in more 
traditional engineering courses such as 3505ENG Heat and Mass Transfer (Woodfield, Hall, and Tansley 2015).

One challenge in implementing project-based learning is that the lecturer needs to focus on a driving question and link concepts and diverse activities, helping the students to construct their own knowledge rather than to didactically teach single subjects. It requires simultaneous changes in curriculum, instruction, and assessment practices (Mapes 2009).

\section{Experiential learning}

Experiential learning is a philosophy of education which has become popular over the last decades. The theories build on social and constructivist theories of learning, but situate experience at the core of the learning process. According to (Beard and Wilson 2006), experiential learning is the sense-making process of active engagement between the inner world of the person and the outer world of the environment. The essence of experiential learning is learning by doing. This is well aligned with a famous proverb attributed by some to Confucius (551 BC-479 BC), which stated that 'I hear and I forget; I see and I remember; I do and I understand' (Vaillancourt 2009). The development of a holistic model of the experiential learning process and a multilinear model of adult development has been introduced by Kolb (1984). Kolb’s model of experiential learning was created out of four elements: concrete experience, observation and reflection, the formation of abstract concepts and testing in new situations - see Figure 1. It is acknowledged that meaningful experiences can lead to a change in an individual's knowledge and behaviours. In spite of some critiques on experiential learning theory such as that presented by (Mughal and Zafar 2011), the great strength of experiential learning is that it provides an underpinning philosophy 
that acts as a thread joining many of the learning theories together in a more unified whole (Beard and Wilson 2006).

For teaching and learning engineering courses in higher education, the role of experience is of special concern, and therefore experiential learning can be suitably used (Lynch and Russell 2009; Wood et al., 2005). Experiential learning has been applied to several engineering disciplines, such as electronics and electrical engineering (Greene 1992; Zhan, Porter, and Morgan 2013; Kim and Thomas 2008; Bakr 2015; Konak, Clark, and Nasereddin 2014). Ayob et al. (2011) reported that experiential learning activities can help to nurture and enhance student creativity dimensions in engineering education. According to Kolb’s learning model, an increased use of hands-on activities in a machine design course can add benefit to establish clear relationships between machine design principles and the reality of machine components, and thus provide a foundation for teaching to the full spectrum of student learning styles (Wood, Jensen, and Wood 2005). Verner and Korchnoy (2004) demonstrated that when students were involved in the experiential learning process, it was effective for understanding engineering and educational concepts. It has been shown by Lynch and Russell (2009) that experience can be the best of teachers, when properly partnered with theory. Kolb’s Experiential Learning Cycle has also been used as a framework to design hands-on activities in virtual computer laboratories (Konak, Clark, and Nasereddin 2014). Aung and Zhou (2015) carried out a pilot study in two mechanical engineering courses using learning modules based on the experiential learning model, and found that students who experienced the theory through hands-on experimentation improved their understandings of course materials significantly. Imperial College London has designed a practical teaching programme based on the experiential learning theory to support student-centred learning, which has received positive feedback from both teachers and 
students (Chen, Shah, and Brechtelsbauer 2016). For a machine design course with project-based learning units, it is clear that students should be exposed to experiential learning cycles to improve the effectiveness and to enhance their learning.

\section{Course redesign methodology}

In the School of Engineering at Griffith University, the course 2505ENG Design of Machine Elements has been a core course for the second year mechanical engineering students. It is aimed at integrating and applying prior knowledge in fundamental design (1006ENG Design and Professional Skills), materials sciences (1502ENG Engineering Materials), and statics and dynamics (1501ENG Engineering Mechanics, 2101ENG Engineering Mechanics, and 2517ENG Kinematics and Dynamics) in the context of machine design. This course builds on previous mechanical design experience in 2502ENG Mechanical Engineering Design where students compete in the Warman Design and Build competition (see https://www.engineersaustralia.org.au/warman). According to the intended learning outcomes, after successfully completing this course, the students should be able to:

1) Apply the formal procedures of detailed machine design, demonstrating that the students understand methods that aid in choosing between competing alternatives in design.

2) Accurately record design calculations and decisions and the reasoning for making decisions in a logbook.

3) Analyse and design a range of machine elements: the physical basis of their operation and design and usage limitations. 
4) Work effectively in teams by: identifying individual roles and responsibility; interacting positively with colleagues; and communicating effectively at group meetings.

5) Communicate as professionals through the production of drawings (computer aided) and through written technical reports.

6) Develop a detailed design of fundamental components in a machine using OEM parts, original designs and parts to Australian and international standards.

Design of machine elements has been considered by students as a difficult course. Previously 2505ENG was designed and delivered in a more traditional way with a focus on transferring knowledge to students via a lecture and tutorial format. It resulted in difficulty in engaging students in deep learning and hindered students from constructing knowledge from their own practical experiences. Although a 'small' scale project-based learning approach had been attempted in this course, the lack of integration with the method of instruction, curriculum and assessment resulted in poor student outcomes - some students experienced difficulties in producing a successful design outcome. Many students have not had significant experience with design projects outside the engineering undergraduate curriculum and many have never even seen a real gearbox. Therefore, to improve student engagement and learning experience in machine design, 2505ENG Design of Machine Elements was redesigned for Semester 2, 2015. The course redesign and implementation centred on Kolb’s experiential learning model with project activities focusing on motivating students through experiential, authentic, and challenging experiences. The details are introduced as follows. 


\subsection{Design preparation with a gearbox exploring project}

The Design of Machine Elements course aims to equip students with relevant theoretical and practical skills to model and design machine elements in some detail. The main focus is the students' acquisition of strong analytical knowledge of machine elements, their design and load carriage and power transmission mechanics. This unit was delivered through a combination of lectures on theories and basics of mechanical engineering design, problem solving tutorials, and design workshops. The number of student was around 70-80. Contact hours in each of the 13 weeks of semester included 2-hour lectures, 2-hour workshops, and 2-hour tutorials. The weekly learning activities are shown in Table 1. The assessment plan for the course is summarised in Table 2 . The design workshops were scheduled to start in the second week of the semester, and gearbox exploration and design were key content for the students' hands-on activities. A briefing on gears trains was provided in week 1 after the course introduction, and a lecture on the general theory of gears was brought forward to week 3, so that the students could be better prepared for the workshop activities.

In phase 1 of the workshop activities, students explored and examined a real world 3-speed gearbox used in a manual car transmission (shown in Figure 2) as the Project 1. Students formed project teams with 5-6 members in a group. Four sets of the gearboxes were placed in the design lab. A YouTube video clip was played to the class to show the working principles of manual transmission systems. After that, students started their hands-on activities to explore the gearbox models, which included to identify the types of gears, count the number of teeth on all gears, figure out the transmission ratios, describe the power path through the transmission, determine the output shaft torque under given input condition for different gears, develop a basic sketch of the gearbox layout, and to record their findings in the first project report. A 
specific set of input condition parameters, such as power rate and speed, were assigned to each team. Through this exploring practise, students became familiar with the main components in a gearbox, and knew about the connections, working principles, materials and relative dimensions.

\subsection{Application-oriented design project task}

In phase 2, students were asked to design a gearbox based on a set of assigned conditions using the knowledge they had learned or were learning. The design project was arranged with a specific application background, which was from a demand for the development of a Formula SAE car by the Griffith Racing Team. Formula SAE is a student design competition held in many countries every year (Kjellberg, Adawi, and Brolin 2015). The student teams design, fabricate test and race a small racecar prototype based on a series of rules. The Formula SAE has been implemented as a design-buildtest course or integrated as part of the undergraduate curriculum in some universities to enhance project-based learning education. Bullen and Karri (2002) discussed the benefits achieved through the design and construction of a Formula SAE racecar as part of mechanical engineering curriculum. It was proven as an effective tool to extend formal lectures and to develop life-long generic skills. Kjellberg, Adawi, and Brolin (2015) pointed out that running the Formula SAE project as a course within the educational organisation has both benefits and challenges. The challenges included the holistic perspective of the project, rookie teams, and lack of required multi-disciplinary teacher teams. Our course adopted a simplified design task for the Formula SAE racecar, i.e., to design a two-stage speed reducer with a fixed transmission ratio. It was aimed at replacing the standard gearbox so as to reduce weight and to eliminate gear changes. The student design teams were asked to determine the configuration and key 
parameters, to design for the strength and functionality, and to create the engineering drawings. The leader of the Griffith Racing Team was invited to give a briefing on the development of the Formula SAE car, challenges and opportunities. Linkage with an actual application was able to inspire the students' enthusiasm for the design project.

\subsection{Design implementation and assessment}

In the design implementation, the project was divided into a series of subtasks with specific milestones, so that the design progress could be handled easily by students. At the beginning of each workshop, the lecturer gave a brief review of the relevant content, either from the lectures or from related engineering theories, and provided specific design and calculation examples, to facilitate students’ design activities for each subtask. Each design team then worked on the subtask. Small group sessions were allocated for the group activities of 15-20 minutes per task. Students in a team worked together for the design calculation and decision making. The outcomes from the subtask were reviewed with the whole class for another 10-15 minutes. Students were given alternative chances to present their results, and to answer questions from peers. The lecturer, as a facilitator, provided individualised feedback when necessary. Then the workshop would move onto next subtask.

During the design workshop, in addition to using a range of teaching models and video clips to demonstrate the working principles of a mechanism or a machine element, the lecturer also encouraged students to use software tools in their design work. For example, a software package MITCalc was recommended to students, which was developed by the software development office 'Miroslav Petele, Ing.' in Czech Republic. It is a set of engineering calculation tools that can be used through the design of machine components. It contains design and check calculations for many common 
tasks in machine element design, such as gears, bearings, shafts and shaft connections. The package was available from the supplier’s website (http://www.mitcalc.com). MITCalc is an open system designed in Microsoft Excel to which students can make further modifications. Students could get 30 days to freely test the product, which was quite helpful for their design work. If they liked the product after trying it out, they could choose to purchase it at an affordable price. The lecturer also provided some home-developed Excel-based toolkits which were nearly-ready, but further work was still needed by the students to make the toolkits ready for using in the design calculation, such as for the gear counter-shaft load calculation, gear bending stress and contact stress calculation. These tools helped to make the tedious design calculations much simplified. Students could focus on mastering the fundamental principles and became fluent in iterative design practice. Students felt it was really fun to use and redevelop the toolkits in their design.

Along with the design work, three sets of short progress reports were to be submitted by each team. Timely feedback from the lecturer was provided to students on the issues to ensure the design was on track. When a design team had the design ready, the designed components could be fabricated by 3D printing. Some samples of 3Dprinted components designed by students are shown in Figure 3. The 3D printed models gave students a means to physically check their design and find out possible issues such as geometrical errors and interference between parts, manufacturability, and assemblability information which could help them to improve their final designs. In the last workshop session, each team made a group presentation to the whole class to introduce their design; each team member was required to play an active role in the presentation. 
The design project contributed to $50 \%$ of the final marks for the course. It consisted of continuous assessment (10 marks), project presentation (10 marks), and final project report (30 marks), as shown in Table 3. The continuous assessment was done by assessing design lab attendance and performance, logbook recording, and meeting design milestones in the three sets of submitted progress summaries. The project presentation was assessed by examining: visual appeal, comprehension, presentation skills, content, and collaboration. A panel consisting of academics and representatives from the racing car team was formed to assess the presentations. The final project report was graded based on a rubric with the assessment aspects and weight shown in Table 4. The assessment considered report quality (structure, writing, presentation); technical content (design layout, design calculation, component design and selection, technical discussion, etc.); quality of engineering drawings; ease of manufacture and assembly; completeness; and teamwork. The performance of a report in each of the aspects was assessed and classified into one of five categories including excellent (85-100\%), good (65-84\%), satisfactory (50-64\%), unsatisfactory (30-49\%), and poor (0-29\%). Up to $10 \%$ of extra mark could be granted to the design work with exceptional contributions or innovations. Teamwork was assessed based on the team collaboration using the rubric as shown in Table 5. Specifically it was reflected in a group work statement in the report, self and peer assessment, and individual logbook check. In the introduction section of the final report, the group information and roles for each member should be included. It is important to clearly list the contribution from each member to the design work and also to the drafting of the final report. A peerreview strategy was also adopted in the assessment. It was required that a statement of self and peer assessment for individual member contribution should be submitted, which was considered in the mark moderation and adjustment for each student. The 
individual logbook was checked as an evidence of the contribution from each member. All the assessment was conducted by the lecturer and tutor working together, with the marking rubrics and sample reports moderated by the course moderator.

\section{Results and Discussions}

The redesign of 2505ENG Design of Machine Elements has focused on the implementation of experiential learning to improve student engagement and learning experience. The learning outcomes and the student performance (in terms of the design project quality) were found to improve, and student engagement has been increased. The student perception of the relevance of this course (and presumably engagement in the course) has significantly improved. This is demonstrated in the results of the Student Experience of Course (SEC) and Teaching (SET) surveys, which are the official university-wide instruments for collecting student feedback on courses and teaching at Griffith University. Before the experiential learning was applied to the course, there were only $26.5 \%$ of the students felt it was satisfactory, and $29.4 \%$ of the students agreed that the teaching on this course was effective in helping them to learn. In comparison, after applying the experiential learning, there was a dramatic improvement. The mean overall satisfactory rate with the quality of the course was increased to a level with $67.7 \%$ of the students considering it satisfactory. The percentage of the students who agreed that the teaching on this course was effective in helping them to learn was also increased to $71 \%$.

The effectiveness of applying the experiential learning theory is also verified from the qualitative feedback of the students. They commented, for example, that 'the project is really good and helped me with understanding the process of how things are created'; 'the level of expertise needed for project 2 (the gearbox design project) was 
high forcing us to put in a lot of effort and learn a lot about gear design', 'The procedure of the assessment was much like the real world design, having to investigate something and be able to design it (felt like I was working on a legitimate project as an engineer)', 'gear-box assignment was really interesting, the course was very interesting overall, love the course'. It is interesting to note that the helpfulness of the gearbox exploring project (Project 1) was appreciated by students, such as that 'The first assignment (exploring gearbox) has provided lot of knowledge for my future course', 'Project 1 was great; easily understood while engaging effective group work and learning’

A main consideration in the redesign of the course was to bring up more 'learning through experience’ cycles so that students could construct their learning more effectively, and also to address the issues that most students were not confident enough for the design project. Thus more concrete issues related to the students and the learning context were focused on. Through the exploration and examination of a real world gearbox, students experienced what a gearbox looks like, how it works, the main geometrical features, and how these features can be associated with the theories they learned in the classroom. Exploration of the gearbox model was the 'concrete experience' stage in an experiential learning cycle for the students. This experience forms 'the basis for observation and reflection' and students got the opportunity to consider what was working and what was not. When conducting the group discussion and completing the first project report on the gearbox exploration, it was a process for the students to reflect on what they observed from the gearbox model, and to think about ways to improve on the next phase. It helped the students to design their own gearbox in phase 2 design project. The previous experience, thought and reflection was followed by new attempt such as design and improvement in a cyclic pattern, which was considered as active experimentation in the experiential learning cycle. 
The redesign of the project activities actively engaged students in the learning process. This was actually a student-centred learning process. It helped them to develop understanding through processes of meaning making. The design workshop was organised in such a way that students could learn better through their experience and reflection. Students experienced many cycles of the four stages of the experiential learning model in the whole design project implementation. Students consciously reflected back on the experience by making clear the working principles. The great strength of experiential learning is that it provides an underpinning philosophy that acts as a thread joining many of the learning theories together in a more unified whole (Beard and Wilson 2006). The group project was arranged to mimic a real industry design environment in terms of team working and timely delivery. It was believed that ‘reality manipulation’ could offer opportunities to unlock learning potential (Beard and Wilson 2006).

It should be mentioned that the whole course, including the lectures, workshop activities, and assessment, was handled by one lecturer with the help of a PhD student as the tutor. While a single facilitator could guarantee the consistency of the teaching and assessment, the teaching load was intensive, and it was difficult to arrange too diverse project tasks. If more teaching resource can be allocated to the course to facilitate the experiential learning in the design workshop, the design tasks can be designed in a more diverse way to match students' interests and competencies, and thus further improvement in the learning experience can be expected.

\section{Conclusions}

The following conclusions can be drawn from this study: 
- Among the mechanical engineering courses, design of machine elements has been considered by students as a difficult course. Traditional teaching by lecturing is not effective in engaging students and thus the learning outcomes are not satisfactory. With a philosophy of learning by doing, experiential learning activities can help to improve the student engagement and their learning for engineering courses.

- A mechanical design course has been redesigned by applying experiential learning theory to improve student engagement and learning experience. The design project and workshop activities have been restructured in such a way that students were engaged in direct experience and focused reflection to construct knowledge.

- Through applying experiential learning to the design workshop activities, the cyclical model of experiential learning has been applied for several times. By exploring the gearbox model, working on subtasks for the design project, participating in group discussions, asking questions, receiving feedback, and moving forward for next subtasks, students experienced the learning cycles of DO, OBSERVE, THINK, and PLAN again and again. In such a way, students have been engaged in a deep learning process through their experience and reflection.

\section{Acknowledgement}

The authors would like to thank Professor Geoff Tansley from Griffith School of Engineering for his support and contribution to this study. 


\section{References}

Aung, K., and J. Zhou. 2015. “Integration of Experiential Learning Modules in Sophomore and Junior Courses : A Pilot Study.” In 2015 ASEE Zone III Conference. Springfield, MO.

https://www.asee.org/documents/zones/zone3/2015/Integration-of-ExperientialLearning-Modules-in-Sophomore-and-Junior-Courses-A-Pilot-Study.pdf.

Ayob, Afida, Aini Hussain, Mohd Marzuki Mustaf, and Muhd Fauzi Aminuddin Shazi Shaarani. 2011. "Nurturing Creativity and Innovative Thinking through Experiential Learning.” Procedia - Social and Behavioral Sciences 18: 247-54. doi:10.1016/j.sbspro.2011.05.035.

Bakr, Mohamed H. 2015. “Teaching Electronics for Non Electrical Engineers Using Blended Learning and Experiential Learning X R Kno P O.” Proceedings of the Canadian Engineering Education Association (CEEA), 2-5.

Beard, Colin, and John P Wilson. 2006. Experiential Learning: A Best Practice Handbook for Educator and Trainers. Second Edi. London and Philadelphia: Kogan Page. doi:10.1017/s001221730001684x.

Biggs, John, and Catherine Tang. 2011. Teaching for Quality Learning at University. Teaching for Quality Learning at University. 4th editio. Berkshire, UK: Society for Research into Higher Education \& Open University Press.

Bullen, Frank, and Vishy Karri. 2002. "Design and Construction of a Formula SAE Racecar in a Teaching and Research Framework.” In Proceedings of Annual International HERDSA Conference: Research and Development in Higher Education, 74-82. Perth, Australia.

Chen, Wenqian, Umang Shah, and Clemens Brechtelsbauer. 2016. "The Discovery Laboratory - A Student-Centred Experiential Learning Practical: Part I Overview.” Education for Chemical Engineers 17 (0). Institution of Chemical Engineers: 44-53. doi:10.1016/j.ece.2016.07.005.

Greene, J.R. 1992. "Experience-Based Learning in Electrical and Electronic Engineering: An Effective and Affordable Approach.” 3D Africon Conference. Africon '92 Proceedings (Cat. No.92CH3215), 10-13. doi:10.1109/AFRCON.1992.624406. 
Hall, Wayne, Stuart Palmer, and Mitchell Bennett. 2012. “A Longitudinal Evaluation of a Project-Based Learning Initiative in an Engineering Undergraduate Programme.” European Journal of Engineering Education 37 (2): 155-65. doi:10.1080/03043797.2012.674489.

Han, S, R. Capraro, and M.M. Capraro. 2015. “How Science, Technology, Engineering, and Mathematics (Stem) Project-Based Learning (Pbl) Affects High, Middle, and Low Achievers Differently: The Impact of Student Factors on Achievement.” International Journal of Science and Mathematics Education 13: 1089-1113. doi:10.1007/s10763-014-9526-0.

Kim, Charles, and Veronica Thomas. 2008. “AC 2008-854 : A MOBILE STUDIO EXPERIENCE OF EXPERIENTIAL LEARNING IN ELECTRICAL ENGINEERING CLASS Mobile Studio Experience of Experiential Learning in Electrical Engineering Class.”

Kjellberg, K, T Adawi, and K Brolin. 2015. "Challenges in Implementing PBL : Chalmers Formula Student as a Case.” In Proceedings of the 43rd Annual SEFI Conference. Orléans. http://www.sefi.be/conference-2015/CHAP 5. Learning Specifi formats for Engineering Education/56749- M. KJELLBERG.pdf.

Kolb, David A. 1984. "Experiential Learning: Experience as The Source of Learning and Development.” Prentice Hall, Inc., no. 1984: 20-38. doi:10.1016/B978-07506-7223-8.50017-4.

Konak, Abdullah, Tricia K. Clark, and Mahdi Nasereddin. 2014. “Using Kolb’s Experiential Learning Cycle to Improve Student Learning in Virtual Computer Laboratories.” Computers and Education 72. Elsevier Ltd: 11-22. doi:10.1016/j.compedu.2013.10.013.

Lynch, Daniel R., and Jeffrey S. Russell. 2009. "Experiential Learning in Engineering Education.” JOURNAL OF PROFESSIONAL ISSUES IN ENGINEERING EDUCATION AND PRACTICE 135 (1): 31-39.

Mapes, Michele R. 2009. "Effcts and Challenges of Project-Based Learning: A Review,” 1-39.

https://www.nmu.edu/sites/DrupalEducation/files/UserFiles/Files/PreDrupal/SiteSections/Students/GradPapers/Projects/Junak-Mapes_Michele_MP.pdf. 
Mills, Julie \&, and David Treagust. 2003. "Engineering Education - Is Problem-Based or Project-Based Learning the Answer?” Australasian Journal of Engineering Education 3 (2): 2-16. doi:10.1108/13552540210420989.

Mughal, Farooq, and Aneesa Zafar. 2011. “Experiential Learning from a Constructivist Perspective: Reconceptualizing the Kolbian Cycle.” International Journal of Learning and Development 1 (2): 27-37. doi:10.5296/ijld.v1i2.1179.

Palmer, Stuart, and Wayne Hall. 2011. “An Evaluation of a Project-Based Learning Initiative in Engineering Education.” European Journal of Engineering Education 36 (4): 357-65. doi:10.1080/03043797.2011.593095.

Sohel, Ferdous Ahmed, Chris Thorne, Jegatheva Jegathesan, Evgeni Sergeev, and Mohammed Bennamoun. 2011. “Interdisciplinary Learning for Final Year Engineering Projects: Case Studies.” Australasian Association for Engineering Education Conference 2011: Developing Engineers for Social Justice: Community Involvement, Ethics \& Sustainability 5-7 December 2011, Fremantle, Western Australia. Engineers Australia, 498. http://search.informit.com.au/documentSummary;dn=257776766590949;res=IELE NG.

Vaillancourt, Régis. 2009. “2009 Régis Vaillancourt.pdf.” The Canadian Journal of Hospital Pharmacy 62 (4): 272-73.

Verner, I.M., and E. Korchnoy. 2004. “Experiential Learning through Designing Robots and Generating Motion Behaviors.” Proceedings World Automation Congress, 2004. 15 (4): 758-65. doi:10.1109/WAC.2004.185192.

Wood, John, Matthew Campbell, Kristin Wood, and Dan Jensen. 2005. “Enhancing the Teaching of Machine Design by Creating a Basic Hands-on Environment with Mechanical ‘breadboards.”” International Journal of Mechanical Engineering Education 33 (1): 1-25. doi:10.7227/IJMEE.33.1.1.

Wood, John J., Daniel D. Jensen, and Kris Wood. 2005. “Enhancing Machine Design Courses through Use of a Multimedia-Based Review of Mecanics of Materials.” In Proceedings of the 2005 American Society for Engineering Education Annual Conference \& Exposition.

Woodfield, P., W. Hall, and G. Tansley. 2015. “Implementation of an Embedded 
Project-Based Learning Approach in an Undergraduate Heat Transfer Course.” In Proceedings of the 26th Annual Conference of the Australasian Association for Engineering Education - AAEE2015. Geelong, Australia.

Zhan, Wei, Jay R. Porter, and Joseph a. Morgan. 2013. "Experiential Learning of Digital Communication Using LabVIEW.” IEEE Transactions on Education 57 (1): 34-41. doi:10.1109/TE.2013.2264059. 
Figure 1. The Experiential Learning Cycle

Figure 2. A 3-speed gearbox model used in a manual transmission car

Figure 3. Samples of 3D-printed components designed by students 


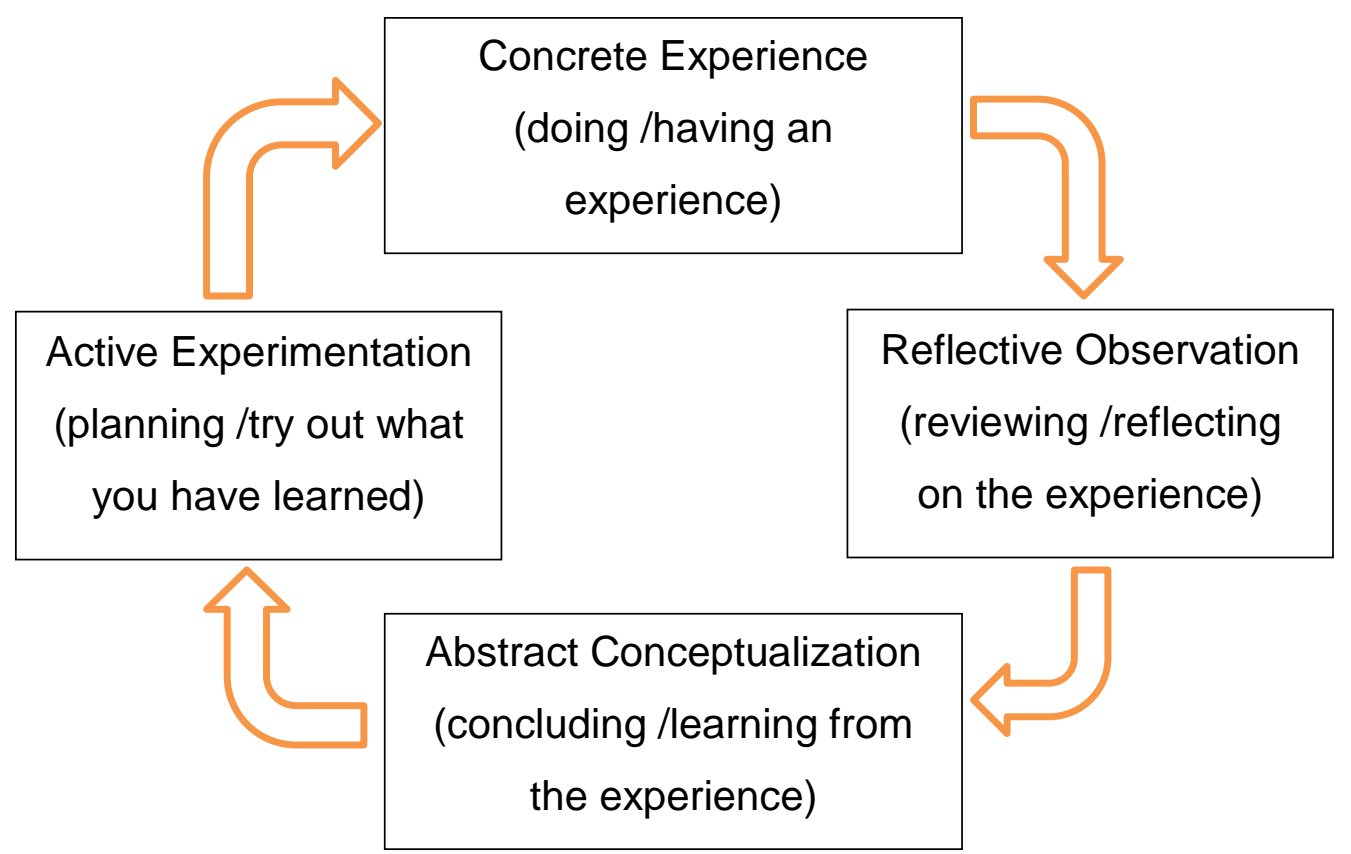

Figure 1

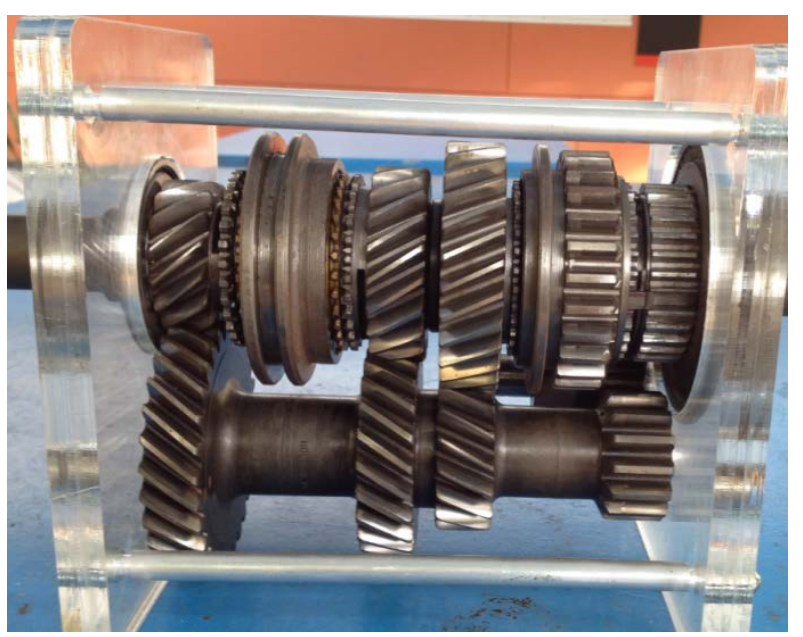

Figure 2 


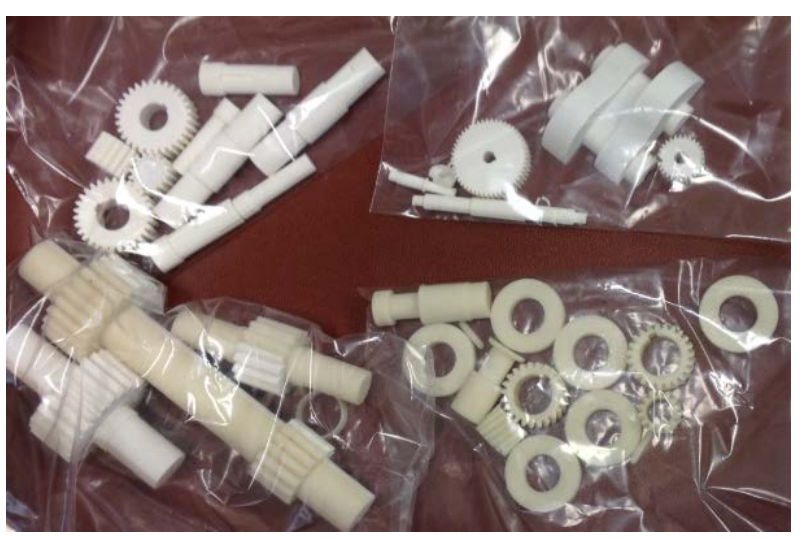

Figure 3 
Table 1. Weekly learning activities

\begin{tabular}{|c|l|l|}
\hline Week & \multicolumn{1}{|c|}{ Lecture } & \multicolumn{1}{|c|}{ Design workshop } \\
\hline 1 & $\begin{array}{l}\text { Course introduction; Briefing } \\
\text { of gear trains }\end{array}$ & \\
\hline 2 & Failures from static loading & Project 1: gearbox exploring \\
\hline 3 & Gears - general theory & Project 1: gearbox exploring \\
\hline 4 & Fatigue failures & $\begin{array}{l}\text { Project 2: task discussion; general } \\
\text { configuration }\end{array}$ \\
\hline 5 & Design of shafts & $\begin{array}{l}\text { Project 2: preparatory size } \\
\text { determination; loading calculation }\end{array}$ \\
\hline 6 & Rolling-contact bearings & Project 2: shaft and key design \\
\hline 7 & Gears - design for strength & $\begin{array}{l}\text { Project 2: bearing calculation and } \\
\text { selection; shaft design revision }\end{array}$ \\
\hline 8 & Review and mid-semester test & Project 2: design for gear strength 1 \\
\hline 9 & Screws and fasteners & $\begin{array}{l}\text { Project 2: design for gear strength 2 } \\
\text { and size adjustment }\end{array}$ \\
\hline 10 & Lubrication and seals & $\begin{array}{l}\text { Project 2: design revision; casing; } \\
\text { engineering drawing }\end{array}$ \\
\hline 11 & Design of joints & $\begin{array}{l}\text { Project 2: miscellaneous items } \\
\text { (sealing, lubrication, etc.), drawing }\end{array}$ \\
\hline 12 & Flexible mechanical elements & $\begin{array}{l}\text { Project 2: design finalizing; 3D } \\
\text { printing; report writing }\end{array}$ \\
\hline 13 & Design project presentation & Design project presentation \\
\hline
\end{tabular}

Table 2. Assessment plan summary for the whole course

\begin{tabular}{|l|c|}
\hline \multicolumn{1}{|c|}{ Assessment task } & Weighting \\
\hline Problem Solving Assignments & $10 \%$ \\
\hline Mid-semester test & $20 \%$ \\
\hline Project 1 - Gearbox exploring & $20 \%$ \\
\hline Project 2 - Gearbox design & $50 \%$ \\
\hline
\end{tabular}


Table 3. Assessment plan for gearbox design project (Project 2. Total weighting: 50\%)

\begin{tabular}{|l|l|c|}
\hline Assessment item & \multicolumn{1}{|c|}{ Description } & Weighting \\
\hline $\begin{array}{l}\text { Continuous } \\
\text { assessment }\end{array}$ & $\begin{array}{l}\text { Assessed by: } \\
\text { Design lab attendance and engagement: } 2 \text { marks. } \\
\text { Logbook recording of design activities: } 2 \text { marks. } \\
\text { Meet design milestones }-3 \text { single page progress } \\
\text { reports: 6 marks (6 = 3×2) }\end{array}$ & $10 \%$ \\
\hline preject & $\begin{array}{l}15 \text { minutes group presentation. Each member must } \\
\text { play an active role. The marking is based on the } \\
\text { technical content and presentation skills. } \\
\text { Assessment panel include lecturer, tutor, and } \\
\text { representatives from the racing car team. Each } \\
\text { student also contributes to assess the presentation } \\
\text { of other groups. }\end{array}$ & $10 \%$ \\
\hline Project report & $\begin{array}{l}\text { Group report is marked according to a rubrics in } \\
\text { terms of Report quality (structure, writing, } \\
\text { presentation), Technical content, Quality of } \\
\text { engineering drawing, Ease of manufacture and } \\
\text { assembly, Completeness, and Teamwork. Peer } \\
\text { assessment for individual member contribution is } \\
\text { included and used for possible adjustment of each } \\
\text { member's final mark. }\end{array}$ & $30 \%$ \\
\hline
\end{tabular}


Table 4. Report marking rubrics: assessment aspects and weight

\begin{tabular}{|l|l|}
\hline \multicolumn{1}{|c|}{ Aspects } & Weight (Marks) \\
\hline Report quality (structure, writing, presentation) & $20 \%(6)$ \\
\hline $\begin{array}{l}\text { Technical content (design layout, design calculation, } \\
\text { component design and selection, technical discussion, etc.) }\end{array}$ & $45 \%(13.5)$ \\
\hline Quality of engineering drawing & $10 \%(3)$ \\
\hline Ease of manufacture and assembly & $10 \%(3)$ \\
\hline Completeness & $10 \%(3)$ \\
\hline Teamwork & $5 \%(1.5)$ \\
\hline Bonus points & Up to 10\% (3) \\
\hline
\end{tabular}

Table 5. Rubric for teamwork assessment

\begin{tabular}{|l|l|}
\hline \multicolumn{1}{|c|}{ Level } & Description \\
\hline $\begin{array}{l}\text { Excellent } \\
(85-100 \%)\end{array}$ & $\begin{array}{l}\text { Team members worked well together and settled differences } \\
\text { in a positive manner. }\end{array}$ \\
\hline $\begin{array}{l}\text { Good } \\
(65-84 \%)\end{array}$ & $\begin{array}{l}\text { Demonstrated good team working skills during the majority of } \\
\text { the time. }\end{array}$ \\
\hline $\begin{array}{l}\text { Satisfactory } \\
(50-64 \%)\end{array}$ & Demonstrated good team working skills part of the time. \\
\hline $\begin{array}{l}\text { Unsatisfactory } \\
(30-49 \%)\end{array}$ & Demonstrated few team working skills. \\
\hline $\begin{array}{l}\text { Poor } \\
(0-29 \%)\end{array}$ & Demonstrated no team working skills. \\
\hline
\end{tabular}

